\title{
A formação de professores primários rurais no estado de São Paulo (1930 - 1971)
}

\section{Resumo}

O texto reconstitui aspectos da história da formação de professores primários para escolas rurais no estado de São Paulo, assinalando a particularidade dessa formação caracterizada pela ênfase nos cursos de especialização e pelo insucesso na instalação das escolas normais rurais. O estudo analisa as propostas e iniciativas do renomado educador ruralista Sud Mennucci para a criação das escolas normais rurais no estado de São Paulo, a normatização que priorizou os cursos de especialização para professores primários rurais e a tardia implantação da Escola Normal Rural, em Piracicaba - SP, em 1956.

Palavras-chave: Formação de Professores para Escolas Rurais. Escola Normal Rural. Educação -São Paulo - História. Educação Rural - São Paulo.

Rosa Fátima Souza Chaloba Universidade Estadual Paulista UNESP - Brasil rosasouzachaloba@gmail.com

\section{Para citar este artigo:}

CHALOBA, Rosa Fátima Souza. A formação de professores primários rurais no estado de São Paulo (1930 1971). Revista Linhas. Florianópolis, v. 18, n. 37, p. 179-209, maio/ago. 2017. 


\title{
Training of rural primary school teachers in the state of São Paulo $(1930-1971)$
}

\begin{abstract}
This paper reestablishes historical aspects of rural primary school teacher training in the state of São Paulo, Brazil, pointing out the particularity of this training, which is characterized by emphasis on specialization courses and by the lack of success in the establishment of the rural teacher education schools. The study analyses the proposals and initiatives of the renowned rural educator Sud Mennucci towards the creation of rural teacher education schools in the state of São Paulo; the regulations which prioritized the specialization courses for rural primary school teachers and the late implementation of the Rural Teacher Training School in Piracicaba, São Paulo - Brazil, in 1956.
\end{abstract}

Keywords: Teachers Training for Rural Schools. Rural Teachers Training School. Education - São Paulo History. Rural Education - São Paulo. 
As propostas e as iniciativas de criação de instituições para a formação de professores rurais intensificaram-se no Brasil, entre as décadas de 1930 e 1970, em decorrência de vários fatores como o crescente êxodo no campo, a disseminação dos ideais ruralistas, as políticas implementadas pelo governo federal para contenção do fluxo migratório e saneamento do interior, a expansão do ensino primário nas zonas rurais de iniciativa dos governos estaduais e municipais e as políticas nacionais para a educação rural. ${ }^{1}$

A necessidade de formação específica para os professores rurais começou a ser propugnada por alguns educadores brasileiros no início do século XX e se fortaleceu no âmbito do ruralismo pedagógico, tendência educacional disseminada no país entre as décadas de 1930 e 1960. No entanto, as primeiras iniciativas efetivadas na rede pública de ensino para esse desígnio, de que se tem conhecimento, foram realizadas no estado de Minas Gerais quando, no final da década de 1920, foram criados os cursos anexos aos grupos escolares destinados a esse tipo de formação. Em 1934, foi criada a Escola Normal Rural, em Juazeiro do Norte, no estado do Ceará e ao longo da década de 1930 foram instaladas escolas normais rurais em alguns estados do nordeste. ${ }^{2}$ No início da década seguinte, o tema ganhou ainda maior visibilidade ao ser discutido no âmbito do VIII Congresso Brasileiro de Educação, realizado em Goiânia, em 1942. ${ }^{3}$

A partir de 1946, com a instituição da Lei Orgânica do Ensino Normal (Decreto-Lei $\mathrm{n}^{\circ}$ 8.530, de 2 de janeiro de 1946$)^{4}$ e dos programas implementados pelo Instituto

\footnotetext{
${ }^{1} \mathrm{O}$ presente estudo é fruto de análises e investigações realizadas no âmbito do projeto temático "História da Escola Primária Rural no Estado de São Paulo (1931 - 1968): circulação de referenciais estrangeiros, iniciativas do Poder Público e cultura escolar", financiado pela FAPESP - Fundação de Amparo à Pesquisa do Estado de São Paulo, no período de 2012 a 2015. Este texto compreende versão revista e ampliada da comunicação apresentada no VIII Congresso Brasileiro de História da Educação, realizado em Maringá, no período de 29 de junho a 2 de julho de 2015.

${ }^{2}$ Em Minas Gerais a iniciativa de formação de professores rurais ocorreu no âmbito da reforma Francisco Campos. Segundo Andrade (2006), o Decreto-lei $n^{\circ}$ 5.162, de 20/01/1928, previa que anexos aos grupos escolares de primeira e segunda categorias fossem criados cursos rurais com a finalidade de preparar os professores para a regência nas escolas primárias rurais. Sobre a Escola Normal Rural de Juazeiro, ver, especialmente, Nogueira, 2008, Kulesza, 2010, Araújo, 2011.

${ }^{3}$ Para uma análise detalhada sobre os debates levados a termo nesse Congresso sobre educação rural, ver, entre outros: Prado, 2000; Paes, 2011; Araújo, 2012.

${ }^{4}$ De acordo com esse decreto-lei, o ensino normal seria ministrado em dois ciclos: o primeiro destinado a regentes de ensino primário, com quatro anos de duração e o segundo, o curso de formação de professores primários, com três anos de duração. Previa ainda três tipos de estabelecimentos de ensino normal no país: curso normal regional, a escola normal e os institutos de educação. O ensino normal poderia oferecer cursos de especialização para professores primários e cursos de habilitação para
} 
Nacional de Pesquisas Educacionais (Inep) de apoio aos estados para a expansão do ensino primário nas zonas rurais, vários estados brasileiros implantaram políticas para o magistério primário rural instalando Escolas Regionais Rurais com vistas à formação de professores. $^{5}$

No estado de São Paulo, a formação do professor primário rural teve um encaminhamento bastante peculiar. Enquanto a maioria dos estados brasileiros implantou escolas normais regionais (de $1^{\circ}$ grau), em São Paulo, apesar das tentativas frustradas de Sud Mennucci de criação, nesse estado, de uma escola normal rural de $2^{\circ}$ grau altamente especializada, prevaleceram os cursos rápidos de especialização para professores para atuação nas zonas rurais.

O objetivo deste texto é reconstituir a história da formação de professores rurais no estado de São Paulo analisando as propostas dos educadores e as iniciativas levadas a termo pelos governos do estado para esta formação especializada do professor primário. Para a realização deste estudo, utilizamos como fontes de pesquisa a legislação sobre o ensino normal, os Anuários do Ensino do Estado de São Paulo, mensagens dos governadores enviadas à Assembleia Legislativa, livros produzidos na época sobre o assunto e artigos publicados em periódicos educacionais - na revista Educação e na Revista do Professor, além de matérias publicadas no jornal O Estado de S. Paulo (OESP). O texto aborda três aspectos: as propostas e iniciativas de Sud Mennucci para a criação das escolas normais rurais no estado de São Paulo, a normatização que priorizou os cursos de especialização para professores rurais e a tardia implantação da Escola Normal Rural, em Piracicaba - SP, em 1956.

\footnotetext{
administradores do primário. Os estabelecimentos de ensino normal deveriam manter escolas para prática de ensino (Cf. BRASIL, 1946).

${ }^{5}$ Dentre os trabalhos acadêmicos que abordam a formação de professores rurais em perspectiva histórica de diversas regiões do país, podem ser destacados os seguintes: Andrade, 2006; Pinto, 2007; Pincer, 2008; Werle e Metzler, 2010; Barros, 2011; Santana, 2011; Hervatini, 2011; Piacentine, 2012; Sangenis e Considera, 2013; entre outros.
} 


\section{As batalhas de Sud Mennucci em defesa da criação da Escola Normal Rural no estado de São Paulo}

Sud Mennucci, um dos mais renomados lideres do pensamento ruralista no Brasil, teve papel proeminente na defesa da criação das escolas normais rurais públicas no estado de São Paulo e no país. ${ }^{6}$ Entre os vários escritos desse educador sobre o tema, destaca-se o livro A Crise Brasileira de Educação, no qual ele sistematizou suas posições em relação ao problema do ensino rural no país. ${ }^{7}$ Para Sud Mennucci, a escola primária existente no campo não atendia as necessidades do trabalhador rural, uma vez que ela estava ancorada em valores da vida citadina reforçando, assim, o apreço pela cultura urbana ao invés de favorecer a mentalidade agrícola que deveria prevalecer na população rural. Para solucionar o problema, ele era favorável à diferenciação regional das escolas primárias adaptadas ao meio. Nesse sentido, para as zonas rurais, propunha uma escola primária com feição rural impregnada dos valores do meio e capaz de combater o êxodo do campo. No entanto, em sua opinião, não bastava criar outro tipo de escola, era também imprescindível um novo tipo de professor formado na escola normal rural. "Há quarenta anos, senhores, que o recrutamento do magistério rural prejudica o país. Já o frisei mais de uma vez e torno a repeti-lo (...) (MENNUCCI, 2006, p. 12). Segundo o educador, era preciso romper com o círculo vicioso: “[...] o professor não gosta do campo porque o campo é atrasado. E o campo não progride e não melhora porque não há quem o impulsione, quem lhe dê anseios de perfeição, enfim, porque o professor não lhe dá o seu entusiasmo" (MENNUCCI, 2006, p. 12). Cabia, portanto, criar o tipo de professor rural totalmente diferenciado: “[...] voltado diretamente para o campo, indiferente, senão mesmo quase antipático, à cidade, tipo de homem que se proponha incentivar, através do prestígio de sua irradiação pessoal, o conforto do campo e a formação de uma

\footnotetext{
${ }^{6}$ Sud Mennucci formou-se na Escola Complementar de Piracicaba e atuou vários anos como professor primário. Em 1920, comandou o recenseamento escolar durante a Reforma Sampaio Dória. Em 1927, dirigiu o recenseamento escolar no Distrito Federal, convidado por Fernando de Azevedo, responsável pela Reforma da Instrução Pública no Rio de Janeiro. Entre 1925 e 1931, ele atuou como redator e crítico literário do jornal O Estado de S. Paulo. Sobre a trajetória profissional de Sud Mennucci, ver Monarcha, 2007 e Fonseca, 2014.

7 O livro A crise brasileira de educação foi publicado pela primeira vez em 1930 sendo laureado pela Academia Brasileira de Letras, em 1933, recebendo o $1^{\circ}$ prêmio no concurso da série "Francisco Alves", subordinada ao título "Qual o melhor meio de disseminar o ensino primário no Brasil". Em 1934, o livro teve nova edição, à qual foram inseridos textos e anexos. Neste estudo, estamos utilizando a versão para eBook, de 2006, referente à digitalização da $2^{\mathrm{a}}$ edição em papel de 1934.
} 
consciência agrícola" (MENNUCCI, 2006, p. 12). Nos termos defendidos por Mennucci, esse novo tipo de professor deveria ser formado com base em três diretrizes básicas: ser um profissional entendido de agricultura, um mestre que pudesse ser um enfermeiro dominando conhecimentos da medicina e, acima de tudo, um líder cultural incentivador do progresso do meio.

Ao assumir a Diretoria Geral do Ensino do estado de São Paulo, em 24 de novembro de 1931, Sud Mennucci buscou colocar suas concepções ruralistas em prática. Na revista Educação, órgão da Diretoria Geral do Ensino do Estado de São Paulo, ele expôs o seu programa de trabalho apostando na reforma do ensino rural pautada na criação de grupos escolares rurais e escolas isoladas vocacionais, além de escolas normais rurais ( $\mathrm{MENNUCCl,1931).} \mathrm{A} \mathrm{presença} \mathrm{do} \mathrm{reconhecido} \mathrm{ruralista} \mathrm{na} \mathrm{direção} \mathrm{do} \mathrm{ensino} \mathrm{pode}$ ter motivado alguns municípios paulistas a pleitearem a criação da escola normal rural nas respectivas localidades, como o caso da Prefeitura de Jaboticabal que, em dezembro de 1931, ofereceu ao governo do Estado dois prédios para o funcionamento de uma escola normal desse tipo. ${ }^{8}$

Em março de 1932, Mennucci encaminhou ao Secretário de Estado da Educação e Saúde Pública uma proposta de projeto de decreto, com vistas à efetivação da reforma. ${ }^{9}$ Nesse decreto estava prevista a criação de cinco escolas normais rurais no interior do estado de São Paulo destinadas à formação especializada para o magistério rural. Tais escolas compreenderiam um curso complementar de três anos e um curso normal de quatro anos. O curso complementar destinava-se à formação geral do normalista incluindo apenas a disciplina de agricultura prática como forma de iniciação. Não obstante, a formação profissional dos normalistas rurais era bem abrangente e aprofundada envolvendo Português, Matemática (compreendendo trigonometria retilínea e esférica e mecânica), Física, Química, Botânica, Geografia Econômica e Historia da Civilização, Desenho, Música, Educação Física, Psicologia, Pedagogia e Didática e disciplinas técnicas em agricultura: Tecnologia Agrícola, Zootecnia, Agricultura Geral,

\footnotetext{
${ }^{8}$ De acordo com notícia publicada no jornal O Estado de S. Paulo, em 13 de dezembro de 1931, os edifícios oferecidos pela Prefeitura ao governo do Estado foram construídos para a Escola Municipal de Agricultura e Veterinária de Jaboticabal que funcionou pouco mais de um ano. Os prédios e o terreno ficavam a três quilômetros da cidade. (ENSINO RURAL, 1931, p. 5).

${ }^{9}$ A proposta de Sud Mennucci para a reforma do ensino rural foi divulgada na revista Educação, em 1932. (Cf. COMO DEVERIA SER..., 1932).
} 
Agricultura Especial, Economia Rural, Higiene, puericultura e profilaxia rural. O projeto previa ainda que, nas Escolas Normais Rurais, os trabalhos escolares seriam realizados em dois períodos - um para a parte prática, com aulas no campo e nos laboratórios e outro de aulas teóricas, em classe. Cada escola normal rural deveria contar com um grupo escolar rural e com escolas isoladas vocacionais rurais para a prática e observação dos normalistas. ${ }^{10}$ Para inscrever-se, o candidato deveria fazer exame de admissão ao $1^{\circ}$ ano do curso normal e ter 14 anos completos e, para atrair candidatos a essas escolas, o diretor do ensino propunha que as nomeações para os cargos de diretores e professores dos grupos escolares rurais e escolas isoladas vocacionais, ficassem reservadas aos professores diplomados pelas Escolas Normais Rurais.

Numa entrevista dada ao jornal O Estado de S. Paulo, no início de abril de 1932, Sud Mennucci expôs detalhes do projeto de lei sobre a reforma do ensino rural destacando a centralidade da formação de professores para a melhoria da educação no campo.

É indispensável nos convencermos, de uma vez para sempre, que o methodo até agora usado de mandar para a roça o mestre das cidades é o descalabro completo, que se vae reflectir immediata e directamente sobre as fontes de producção do paiz. A escola urbana enxertada á força na organização do trabalho rural criou o desprezo da vida campesina, o desdém pelo melhoramento dos processos agrícolas e o êxodo dos campos. (A RURALIZAÇÃO DO ENSINO, 1932, p. 4)

Porém, as expectativas do educador foram malogradas, pois, em 24 de maio de 1932, ele foi demitido do cargo e o decreto foi engavetado. Inconformado com a saída da Diretoria do Ensino e com os comentários veiculados na imprensa paulista e carioca sobre a reforma, Sud Mennucci publicou, em 1932, o livro intitulado O que fiz e pretendia fazer buscando rebater as críticas que lhe foram desferidas e reafirmar as suas posições em relação à reforma do ensino rural. No que diz respeito à formação dos professores, Mennucci reiterou nesse livro suas posições a favor da relevância de formação de um

\footnotetext{
10 As matérias do curso complementar envolviam: Português, Francês, Matemática (compreendendo aritmética, álgebra e geometria), Geografia e Historia do Brasil, Ciências físicas e naturais, Agricultura prática, Desenho, Música, Educação Física. Constavam no referido decreto, como finalidades dos grupos escolares e escolas isoladas vocacionais "[...] a formação de uma mentalidade escolar francamente voltada para as atividades agrícolas e pastoris, e, na zona marinha, para as fainas marinhas e ribeirinhas" (COMO DEVERIA SER..., 1932, p. 3).
} 
novo tipo de professor, amante da vida rural, um abnegado mestre comprometido com o desenvolvimento das comunidades rurais, um líder comunitário com atuação dentro e fora da escola.

A preocupação do conforto do campo só pode nascer em quem o ame e venere e cultue. E só pode nascer atravez de uma constante obra educativa, persistente e tenaz como um apostolado.

Só o professor poderá fazel-o, mas só o fará o professor que também tenha profunda devoção pelo campo, que lhe conheça as belezas e as riquezas que encerra e também as mazelas que esconde. Assim se explica a minha insistência pela creação das Escolas Normais Rurais, formadoras do mestre com consciência agrícola, conhecedor das necessidades da agricultura, um cavaleiro de seu meio com a cultura e com o nível mental, capaz de vulgarizar a ciência e de pôl-a em evidencia pelos resultados imediatos. Será do mesmo passo um conhecedor das inferioridades locais, um defensor incansável do nível médio da higidez coletiva, atravez de sua experiência individual. E será um pregador sistemático da necessidade da fixação do homem á terra e da formação das sociedades perfeitamente integradas ao seu meio, produto das determinantes geográficas a reagir sobre as características biológicas. (MENNUCCl, 1932, p. 127)

Para formar o professor com essa mentalidade, era preciso que as escolas normais se organizassem

[...] sob um tríplice ponto de vista: o pedagógico, o higiênico ou, talvez melhor, o sanitário, e o agrícola. Isso quer dizer que terão professores propriamente ditos, professores-medicos e professores-agrônomos. Todos, nessa casa, desde a cabeça diretora até o mais humilde servente devem ter "mentalidade agrícola", isto é, de quem sabe que o campo é a esperança atual única do Brasil (...) (MENNUCCI, 1932, p. 127)

Sud Mennucci voltou a ocupar o cargo de Diretor Geral do Ensino do estado de São Paulo por um breve interstício de 17 dias, em 1933 (entre 7 a 23 de agosto), sucedendo Fernando de Azevedo. Apesar dessa breve passagem pela Diretoria, ele conseguiu aprovar o decreto de organização do ensino rural, que ele havia proposto em sua gestão anterior, com pequenas alterações. Enquanto na primeira proposta foi prevista a criação de cinco escolas normais rurais, Mennucci buscou garantir a criação de pelo menos uma escola normal rural no território paulista. 
O Decreto $n^{\circ}$ 6.047, de 19 de agosto de 1933 autorizava a instalação de uma Escola Normal Rural em Piracicaba, indicando que ela deveria manter íntima colaboração com a Escola Superior de Agricultura “Luiz de Queiroz”. Além disso, transformava os grupos escolares de Butantã e “Arnaldo Barreto” de Tremenbé em grupos escolares rurais. Para efeito de fiscalização e inspeção do ensino rural, o decreto criava a Inspeção Técnica do Ensino Rural com os seguintes funcionários: um inspetor-chefe, obrigatoriamente diplomado em agronomia, um inspetor agrônomo, um inspetor-médico e um inspetor escolar. Oficializava ainda em todos os grupos escolares do estado o "Clube Agrícola Escolar", com a finalidade de despertar nas crianças "o gosto e o respeito pelas fainas agrícolas e a compreender os esforços realizados pelos nossos cultivadores e agricultores, no amanho da terra e sua colaboração na riqueza do país" (SÃO PAULO, 1933).

Diferente do que vinha ocorrendo em outros estados, a escola normal rural criada no estado de São Paulo era de $2^{\circ}$ ciclo, pressupondo assim, uma formação de nível superior àquela oferecida nas Escolas Normais Regionais. Pode-se dizer, portanto, que Sud Mennucci conseguiu criar legalmente uma escola normal rural pública em São Paulo, porém, não logrou efetivar a sua instalação. Nem mesmo quando voltou a ocupar a Diretoria do Ensino pela terceira vez, entre 1943 e 1945, ele pôde concretizar tal proposta. Por que haveria falhado o projeto de instalação da escola normal rural em Piracicaba? Pelo menos duas hipóteses podem ser aventadas: por um lado, é preciso considerar as diferentes concepções de educação rural defendidas por educadores e administradores do ensino paulista destacando-se, por exemplo, as disputas entre partidários da escola comum e defensores do ruralismo pedagógico; por outro lado, em que pesem os acordos estabelecidos entre a União e os Estados, por meio do Instituto Nacional de Pesquisas Educacionais (Inep) para o desenvolvimento das escolas primárias rurais, os governos paulistas mantiveram políticas próprias de expansão da educação rural, principalmente em relação ao chamado "ensino típico rural"."

\footnotetext{
${ }^{11}$ No estado de São Paulo, o ensino típico rural envolveu a instalação de grupos escolares rurais, granjas escolares e escolas típicas rurais. Como bem definiu o governador Jânio Quadros: “O ensino típico rural é uma modalidade de ensino especializado para a criança da roça. Além de programa próprio, relativo ao aprendizado das atividades agrícolas e higiene rural, caracteriza-se por ser ministrado nos grupos rurais mediante um sistema de estudo teórico-prático, que leva o estudante a comparecer à escola nos dois períodos, da manhã e da tarde. Reveste-se esse menino, por esse fato, de rico conteúdo educativo, como
} 
Nas décadas de 1940 e 1950, o interesse na criação de escolas normais rurais no estado de São Paulo continuou mobilizando a atenção de educadores e políticos. Em 1949, de acordo com notícia veiculada no OESP, a Câmara Municipal de Botucatu apresentou à Câmara Estadual uma indicação sugerindo a criação de uma escola normal rural naquele município, a ser instalada no Lageado - Fazenda Central Experimental do Café (ESCOLA NORMAL RURAL, 1949, p. 5). Porém, o projeto não foi adiante, pois, não recebeu apoio do Ministério da Educação. ${ }^{12}$

Em 15 de maio de 1949, o OESP noticiou na coluna Notas e Informações que o deputado Cunha Bueno havia levado ao conhecimento da Assembleia Estadual a intenção do Ministério da Educação de criar 47 escolas normais rurais pelo território nacional com exceção do estado de São Paulo e lamentava a "inépcia dos administradores paulistas de não aproveitarem o oferecimento do governo federal." A propósito, o articulista do jornal afirmou:

Uma escola normal rural em São Paulo seria certamente um convite à administração estadual para que cuide com carinho dessa importante modalidade de ensino; seria um esforço de "orientação" a indicar o rumo a ser seguido. (...) Ainda é tempo do governo federal voltar atrás e de nos dar uma escola que sirva de modelo a uma política de ensino rural inteligente e na altura de nossas necessidades. (NOTAS E INFORMAÇÕES, 1949, p. 3)

Durante a década de 1950, 31 projetos de lei de criação de escola normal rural foram apresentados à Assembleia Legislativa do Estado de São Paulo. ${ }^{13}$ Esta mobilização

curso de preparação da criança e do adolescente, para as atividades rurais e o convívio social da zona agrícola, em que reside. Constitui tal ensino uma das faces da solução do problema da educação rural, de tão capital interesse para a economia do Estado e o seu progresso político-social" (SÃO PAULO, 1957, p. 63). Estudo pioneiro sobre o ensino típico rural no estado de São Paulo foi realizado por Moraes, 2015.

${ }^{12} \mathrm{Em} 20$ de abril de 1949, o OESP publicou na coluna "Na Assembleia Legislativa" nota informando que os deputados Cunha Bueno e Rubens do Amaral haviam encaminhado à mesa, uma indicação para a criação da Escola Normal Rural de Botucatu (NA ASSEMBLEIA ..., 1949, p. 8). No dia 13 de maio de 1949, outra nota foi publicada nesse jornal afirmando que não seria mais instalada em Botucatu a escola normal rural, pois, embora o deputado Cunha Bueno tivesse ido ao Rio de Janeiro conversar pessoalmente com Murilo Braga, do Departamento de Educação, para solicitar a criação da escola, foi informado que não havia intenção do governo federal em instalar uma escola normal rural no estado de São Paulo (NOTíCIAS DO INTERIOR, 1949, p. 9).

${ }^{13}$ Os projetos de lei apresentados à Assembleia Legislativa previam a criação de novos estabelecimentos de ensino normal ou transformação de escolas normais já existentes em unidades de ensino normal rural a serem instaladas no interior do estado e no litoral. A maioria desses projetos de lei foi proposta pelos 
dos deputados paulistas em prol da formação de professores primários rurais pode ser compreendida tendo em vista o processo de democratização em curso no país e, sobretudo, as políticas para a educação no campo implementadas pelo governo federal e estadual. Contudo, nenhum desses projetos de lei foi aprovado. A instalação da Escola Normal Rural em Piracicaba ocorreu somente em 1956, e mesmo assim, em caráter experimental. Apesar da importância do movimento ruralista na educação do estado de São Paulo e das tentativas de criação de escolas normais no campo, foram os cursos de especialização que se tornaram a orientação dominante na política educacional paulista para a formação de professores para escolas primárias rurais.

\section{Os cursos de especialização de Professores Rurais}

Defensor da escola primária comum, Almeida Junior, por diversas vezes criticou a posição dos ruralistas e posicionou-se contrário à criação das escolas normais rurais em São Paulo propondo, ao contrário, os cursos de especialização. ${ }^{14}$ Em 1936, ocupando o cargo de diretor geral do ensino, ele expôs longamente suas posições no Anuário do Ensino do Estado de São Paulo. Diferentemente de Sud Mennucci, ele não preconizava um professor de tipo rural, mas um simpatizante da vida na roça que possuísse especialização técnica. Nesse sentido, argumentava contra a criação das escolas normais rurais tendo em vista o grande número de escolas normais já existentes em São Paulo:

Esse aspecto do problema não havia escapado ao sr. Sampaio Doria, em 1920, época em que propoz ao Congresso do Estado a creação de uma escola normal em Piracicaba. Eu concordo e bom grado com a idéia, contanto que seja para localizar a escola, não na cidade, mas em plena zona rural. Há, porém, uma razão que, ao menos no momento, me faz

deputados Antonio Oswaldo do Amaral Furlan e Alfredo Farhat. Cf. site da Assembleia Legislativa do Estado de São Paulo: <http://www.al.sp.gov.br/leis/>.

${ }^{14}$ Antônio Ferreira de Almeida Junior nasceu em Joanópolis, São Paulo, em 8 de junho de 1892 e faleceu no dia 4 de abril de 1971. Iniciou suas atividades no magistério em Santos, como professor primário de Escola Isolada. Em 1921, formou-se em Medicina, pela Faculdade de Medicina e Cirurgia de São Paulo. Na década de 1920, lecionou Biologia e Higiene na Escola Normal do Braz e chefiou o primeiro Recenseamento Escolar realizado no estado de São Paulo, em 1920, na vigência da Reforma Sampaio Dória. Entre 1933 e 1936, Almeida Junior exerceu o cargo de Chefe do Serviço Médico Escolar de São Paulo assumindo em seguida (1938 a 1938) o cargo de Diretor do Ensino. Foi catedrático de Medicina Legal da Faculdade de Direito de São Paulo, participou da Comissão de elaboração do anteprojeto da primeira Lei de Diretrizes e Bases e passou a integrar o Conselho Nacional de Educação em 1949, atuando nesse órgão por mais de uma década. Cf. Dicionário de Educadores no Brasil, 2002, p. 131-137 (FÁVERO, BRITO, 2002). 
tergiversar. É a plethóra de escolas normaes no Estado. Temos actualmente 10 escolas normaes officiaes e 43 escolas normaes livres. No anno passado, formaram ellas 1.014 professores, dos quaes 629 couberam ás escolas normaes officiaes e 385 ás normaes livres. Em matéria de estabelecimentos formadores de professores primários, 0 problema no momento é reduzil-os, e não augmental-os. Estão elles a fabricar legiões de desempregados e, portanto, a prestar, sob esse aspecto, um desserviço social. Porque os mil diplomados de cada anno querem, na quase totalidade, vir ensinar na cidade. E muitos dos que concordam em ficar na roça, não conseguem collocação favorável nos concursos. (SÃO PAULO, 1936, p. 190)

Almeida Junior apontava a inconveniência de instalação da Escola Normal Rural alegando o tempo que ela levaria para formar os professores necessários para atuar nas 3.200 escolas primárias rurais em funcionamento no estado de São Paulo, conforme dados referentes ao ano de $1936 .{ }^{15} \mathrm{Na}$ mesma direção, dizia que outros países da América do Sul e da América Central haviam optado por formar um magistério rural de nível inferior, o que não se aplicava a São Paulo que contava com um grande número de professores normalistas e escolas de formação de professores. Na proposta do diretor geral do ensino, os cursos de especialização deveriam ser breves com duração de três ou quatro meses, com aulas diárias teóricas e práticas, abrangendo as matérias e atividades essenciais ao professor rural compreendendo higiene rural, cuidados corporais, sociologia rural e educação rural propriamente dita (SÃO PAULO, 1936, p. 192). Os primeiros cursos de especialização para formação de professores rurais foram oferecidos pela Escola Normal Livre de Santa Rita do Passa Quatro e pela Escola Oficial de São Carlos, no ano de 1936 (EDUCAÇÃO RURAL, 1936).

A Consolidação das Leis do Ensino instituída no estado de São Paulo em 1947 (Decreto $n^{\circ} 17.698$, de 26 de novembro), apesar de sua orientação parcialmente ruralista, manteve os cursos de especialização de professores para o magistério rural. Essa legislação estabeleceu que o ensino normal mantido pelo Estado seria ministrado em escolas normais e no curso normal do Instituto de Educação Caetano de Campos. O curso das escolas normais foi reestruturado compreendendo um curso de formação

\footnotetext{
${ }^{15}$ Como bem demonstraram Viviani e Gil (2011), Almeida Junior valeu-se, inúmeras vezes, de estatísticas oficiais para fundamentar seus argumentos acerca do problema da educação pública paulista. As posições desse educador sobre as escolas normais podem ser encontradas nos Anuários do Ensino de 1935 - 1936 e de 1936-1937 e, ainda no artigo publicado no n² 24 da Revista Brasileira de Estudos Pedagógicos (Cf. ALMEIDA JUNIOR, 1946).
} 
profissional de dois anos, um curso pré-normal, de um ano e um curso primário de quatro anos.

Portanto, pode-se afirmar que no estado de São Paulo, diferente de outros estados da federação, não se cogitou a adoção do Curso Normal Regional, de $1^{\circ}$ ciclo, possivelmente em virtude do desenvolvimento educacional do estado e da existência de um elevado número de escolas normais públicas e particulares de $2^{\circ}$ ciclo.

Em relação aos cursos de especialização, a Consolidação das Leis do Ensino determinou no artigo 425 que o governo manteria, junto aos estabelecimentos de ensino agrícola, cursos apropriados com a duração mínima de 40 semanas que poderiam ser realizados por professores normalistas. O regimento e o programa desses cursos seriam elaborados com a colaboração do Departamento de Educação e íntima colaboração com a Diretoria do Ensino Agrícola, da Secretaria de Agricultura. O artigo 462 incluía uma orientação geral para todo o ensino normal, destinando atenção aos conteúdos de natureza rural. As escolas normais do Estado deveriam manter anexo um horto ou campo para demonstrações e experiências agrícolas e, na impossibilidade de as escolas possuírem tais espaços, os diretores deveriam entrar em entendimento com fazendas, escolas ou hortos agrícolas, que existissem na respectiva região, para realizar os estudos agrícolas rudimentares (SÃO PAULO, 1947).

Em 1948, em mensagem encaminhada à Assembleia Legislativa, o governador Ademar de Barros explicitou o modo como as autoridades políticas e educacionais de São Paulo estavam compreendendo o problema das escolas normais rurais: "A frequência simultânea de cursos paralelos de formação profissional do professor, em escola normal comum, e de monitores agrícolas, em escolas profissionais agrícolas, resulta, para o professorando, no curso das escolas normais rurais, tão preconizadas em nosso meio." (SÃO PAULO, 1948, p. 74). O governador informava que as escolas profissionais agrícolas de Pinhal, Jacareí e São Manoel estavam autorizadas a receberem os alunos das escolas normais oficiais daquelas mesmas cidades, "numa permuta e coordenação de recursos técnicos e docentes pela primeira vez encetadas no ensino paulista, para a nobre empreitada de melhorar as condições de vida do trabalhador do campo" (SÃO PAULO, 1948, p. 74). 
As indicações para a formação dos professores primários rurais estabelecidas na Consolidação das Leis do Ensino de 1947 foram mantidas no Regimento Interno das Escolas Normais Oficiais do Estado, de 1950 (Decreto n 19.525-A, de 27 de junho de 1950). Nota-se, portanto, o prevalecimento na legislação educacional paulista de uma orientação contrária à criação das escolas normais rurais. A incorporação de alguns conteúdos e práticas agrícolas nos programas do ensino normal do estado reiterava, assim, a posição dos defensores da escola comum, ao mesmo tempo em que atestava as vicissitudes do ruralismo pedagógico no território paulista.

No âmbito dos nossos estudos, ainda não foi possível identificar a quantidade e a localidade dos cursos de especialização de professores rurais que foram realizados no estado de São Paulo, no período de 1930 a 1970. No entanto, alguns registros permitem confirmar a existência desses cursos em alguns estabelecimentos de ensino normal oferecidos conjuntamente com a Secretaria de Agricultura.

Por exemplo, na mensagem enviada à Assembleia Legislativa, em 1952, o governador Lucas Nogueira Garcez registrou a realização, em julho de 1951, de um curso rápido de férias para o professorado especializado do ensino rural (SÃO PAULO, 1952). Na mensagem de 1956, o governador Jânio Quadros assinalou que o curso de monitor agrícola, que funcionava nas Escolas Agro Técnicas de Pinhal, Jacareí e São Manoel, numa cooperação do Departamento de Ensino Profissional com o trabalho educacional da Assistência Técnica do Ensino Rural do Departamento de Educação, continuara oferecendo, em 1955, o curso de especialização de professores para o magistério rural. O governador notificava, ainda, a realização de cursos intensivos de férias, envolvendo as seguintes especialidades: agricultura, piscicultura, apicultura, laticínios e atividades agrícolas gerais, na Capital, Cotia e Piracicaba, com uma frequência total de 541 professores-alunos (SÃO PAULO, 1956).

No final da década de 1950, os cursos de especialização de professores primários rurais foram normatizados na estrutura do ensino normal de São Paulo. A Lei $n^{\circ} 3.739$, de 22 de janeiro de 1957, estabeleceu que o ensino normal seria ministrado em escolas normais e nos Institutos de Educação, podendo esses últimos oferecerem cursos de preparação de professores primários para o ensino rural e de especialização para o ensino de deficientes mentais, cegos e surdos-mudos. Em 1959, uma nova legislação alterou a 
organização do ensino normal paulista (Decreto $n^{\circ}$ 35.100, de 17 de junho de 1959) determinando que a formação de professores seria ministrada nos Cursos de Formação, de Aperfeiçoamento e de Especialização. ${ }^{16}$ Portanto, essa nova legislação normatizou o curso de Especialização de Professores de Ensino Primário Rural fixando a duração do curso em um ano, compreendendo as seguintes disciplinas: 1) Sociologia Rural; 2) Higiene e Saneamento Rurais; 3) Noções Gerais de Economia Agrária; 4) Noções de Agricultura Geral e Especializada; 5) Noções de Zootecnia; 6) Metodologia do Ensino de Higiene Rural e das atividades agrícolas. As repercussões e o impacto desses cursos de especialização de professores rurais no magistério paulista necessitam ser dimensionados. Não obstante, para isso são imprescindíveis investigações no âmbito da história das instituições educativas que possam identificar os Institutos que ofereceram o curso de especialização para professores rurais, a clientela atendida, entre outros aspectos.

No entanto, interessa destacar que, as mudanças introduzidas na formação de professores primários no país, pela Lei de Diretrizes e Bases de 1961, pode ter impactado o oferecimento desses cursos de especialização no estado de São Paulo. Por um lado, a Lei de Diretrizes manteve os dois níveis do ensino normal ( $1^{\circ}$ e $2^{\circ}$ ciclos), por outro lado, deu ênfase à formação de professores para as novas funções técnicas no âmbito da supervisão e orientação educacional. Pela Lei de Diretrizes e Bases, a finalidade do ensino normal passou a ser a formação de professores, orientadores, supervisores e administradores escolares destinados ao ensino primário (BRASIL, 1961). A formação de professores primários seria ministrada nos seguintes estabelecimentos de ensino: a) na escola normal de grau ginasial com quatro séries cujo diploma seria de regente de ensino primário e, b) na escola normal de grau colegial, de três séries anuais, cujo diploma seria de professor primário; c) nos Institutos de Educação que, além dos cursos de grau médio, ministrariam cursos de especialização, de administradores escolares e de

\footnotetext{
${ }^{16} \mathrm{O}$ Decreto $\mathrm{n}^{\circ} 35.100$, de 17/06/1959 regulamentou a Lei $\mathrm{n}^{\circ}$ 3.739, de 22 de janeiro de 1957, que dispôs sobre a organização do Ensino Normal no estado de São Paulo. De acordo com esse decreto, o Curso de Formação destinava-se a formar professores para o ensino primário comum; o Curso de Aperfeiçoamento serviria para o aperfeiçoamento dos professores primários e, o de Especialização, para a formação de professores primários para a administração escolar e para o ensino. Foram estabelecidos os seguintes cursos de Especialização: a) Administradores Escolares; b) Professores de Educação Pré-Primária; c) Professores de Ensino Primário Rural; d) Professores de Deficientes Mentais; e) Professores de Cegos; f) Professores de Surdos.
} 
aperfeiçoamento. Em relação à formação de professores para o ensino rural, o tratamento dado pela Lei de Diretrizes e Bases foi superficial indicando tão somente que: "A formação de professôres, orientadores e supervisores para as escolas rurais primárias poderá ser feita em estabelecimentos que lhes prescrevem a integração no meio" (art. 57, Lei $\left.n^{\circ} 4.024 / 61\right)$.

Antes mesmo da publicação oficial da LDB, o governador Carlos Alberto Alves de Carvalho Pinto sancionou, em 1961, alguns decretos instituindo o Regimento Interno dos Estabelecimentos de Ensino Secundário e Normal do estado de São Paulo em consonância com as propostas em discussão no âmbito da LDB. ${ }^{17}$ Pelo Decreto $n^{\circ} 39.334$, de 10 de novembro de 1961, o ensino normal mantido pelo Estado passaria a ser ministrado em três tipos de unidades escolares: 1) no Ginásio Estadual e Escola Normal (G.E.E.N.), estabelecimento de ensino que manteria o primeiro ciclo do ensino secundário (curso ginasial) e mais o curso de formação de professores primários, podendo manter também, o curso de aperfeiçoamento para professores primários; 2) no Colégio Estadual e Escola Normal (C.E.E.N.), estabelecimento de ensino que manteria os dois ciclos do secundário e o curso de formação de professores primários, podendo manter também, o curso de aperfeiçoamento de professores primários, e, 3) nos Institutos de Educação (I.E.), estabelecimento de ensino destinado a manter, além dos cursos próprios da escola normal, um ou mais de especialização, podendo manter o curso secundário, nos dois ciclos. Considerando que o Regimento não detalhou normas para os Cursos de Especialização, pode-se inferir que tenham permanecido as alternativas fixadas na normatização de 1959 que previa, entre outros, o Curso de Especialização de Professores Primários Rurais de um ano de duração. ${ }^{18}$ Não obstante, a partir do Código de Educação do Estado de São Paulo de 1968 (Lei n 10.125, de 4 de junho de 1968), não aparece mais na legislação do ensino normal paulista menção à formação de professores primários rurais.

\footnotetext{
${ }^{17}$ Sobre o Regimento Interno dos Estabelecimentos de Ensino Secundário e Normal, consultar a seguinte legislação: Decreto $n^{\circ} 38.538$, de 2 de fevereiro de 1961; Decreto $n^{\circ} 38.634$ de 23 de junho de 1961 e Decreto $\mathrm{n}^{\circ} 39.334$, de 10 de novembro de 1961.

${ }^{18}$ Sobre a legislação paulista acerca do ensino normal no final da década de 1960 , ver, entre outros: Lei $\mathrm{n}^{\circ}$ 10.038, de 5 de fevereiro de 1968 - dispõe sobre a organização do sistema de ensino do Estado de São Paulo; Lei n $\mathrm{n}^{\circ}$ 10.125, de 4 de junho de 1968 - Institui o Código de Educação do Estado de São Paulo; Decreto $\mathrm{n}^{\circ}$ 50.133, de 2 de agosto de 1968 - Regulamenta a Lei ${ }^{\circ}$ 10.038, de 5 de fevereiro de 1968.
} 
Ao que tudo indica, o problema da educação primária rural sofreu uma forte inflexão em todas as regiões do país no final da década de 1960. O período foi marcado pela intensa urbanização e o consequente êxodo rural, pela modernização da economia agrária e pela reconfiguração econômica, demográfica e sociocultural das áreas rurais. No que diz respeito ao campo educacional, a agenda política foi pautada pela relação entre educação e desenvolvimento econômico, destacando-se problemas como a erradicação do analfabetismo, a universalização do ensino primário, a ampliação da obrigatoriedade escolar, a formação técnica em nível médio e a necessidade de novas diretrizes para a formação de professores (TANURI, 2000).

\section{A instalação da Escola Normal Rural em Piracicaba}

A história da Escola Normal Rural de Piracicaba - SP necessita de estudos aprofundados. Neste texto, apresentamos dados preliminares encontrados na legislação do ensino, nas mensagens dos governadores, na Revista do Professor e no jornal 0 Estado de S. Paulo que permitem reconstituir alguns indícios da trajetória de instalação e funcionamento desse estabelecimento de ensino.

Como afirmamos anteriormente, várias tentativas de implantação da Escola Normal Rural de Piracicaba foram levadas a termo por políticos e educadores paulistas ao longo das décadas de 1930 e 1950. A primeira criação oficial dessa escola data de 1933 (Decreto $n^{\circ}$ 6.047, de 19 de agosto). Em 1950, o governador Ademar de Barros assinou a Lei $n^{\circ} 881$, de 6 de dezembro de 1950, autorizando a instalação da Escola Normal Rural em Piracicaba, mas novamente o estabelecimento não foi instalado. Finalmente, em 1956, o governador Jânio da Silva Quadros aprovou a instalação dessa instituição em caráter experimental (Decreto $n^{\circ} 25.781$, de 27 de abril de 1956). As considerações arroladas no decreto atestam o reconhecimento do Poder Público acerca da trajetória conturbada da escola normal rural no estado de São Paulo:

Considerando que de longa data se debate São Paulo e no país o controvertido problema da formação profissional de professores para às escolas localizadas no meio rural, cuja realidade social e necessidades educacionais diferem sob importantes aspectos das do meio urbano; Considerando que, apesar de se dividirem as opiniões dos técnicos, ora 
concluindo em favor da formação especializada, ora sustentando ponto de vista diferente, a matéria é do mais alto interesse público; Considerando que as comissões técnicas e o plenário dos congressos normalistas de educação rural, reunidos sucessivamente em Campinas, Piracicaba, Casa Branca e São Carlos, respectivamente em 1945, 1947,1949 e 1951, não se pronunciaram a favor da instalação de escolas normais rurais no Estado como solução do problema educacional no campo, mas consideraram-na recomendável em têrmos de experiência, Considerando que ao Estado convém seja feita a experiência, a fim de verificar em que medida poderia a Escola Normal Rural contribuir para eventual solução de problemas de educação e ensino no meio rural [...] (SÃO PAULO, 1956)

O Decreto $n^{\circ} 25.781$, de 27/04/1956 manteve o currículo estabelecido pela Lei 881 , de 6 de dezembro de 1950, e também as prerrogativas aos diplomados pela Escola Normal Rural, isto é, a preferência à nomeação para os cargos de Diretor e Professor de Grupos Escolares Rurais e para os cargos de professores das Escolas Típicas Rurais e preferência para o provimento de escolas isoladas e classes de grupo escolar do ensino primário comum, sediadas na zona rural (SÃO PAULO, 1956).

O que teria levado o governador do estado a retomar o antigo projeto de instalação da Escola Normal Rural em Piracicaba? Estaria ele atendendo as reivindicações e pressões de políticos e educadores locais, visto que Piracicaba consagrara-se como “meca do ruralismo" no estado de São Paulo? As notícias publicadas no jornal OESP não permitem responder essas questões, porém, oferecem informações relevantes sobre a institucionalização desse estabelecimento de ensino. Os preparativos para a instalação da escola começaram no mês de março de 1956. Conforme noticiou OESP, em 20 de março a comissão designada pelo diretor-geral do Departamento de Educação reuniu-se em Piracicaba para examinar a possibilidade de instalação da Escola Normal Rural. Essa comissão era presidida pelo chefe do Serviço do ensino Normal, tendo como vicepresidente o assistente técnico do ensino rural, sendo integrada por mais cinco professores, todos ruralistas residentes em Piracicaba (ESCOLA NORMAL RURAL..., 1956, p. 10).

A comissão composta pelos professores Joaquim do Marco, José Armando Furlani, Tercio Emerique, João Criarini, vereador Mario Stalf e professor Jair de Andrade, chefe do Departamento do Ensino Secundário e Normal reuniu-se novamente no dia 15 de abril, 
ocasião em que visitou o Grupo Típico Rural “Prof. Corte Brilho” instalado no bairro Chicó e as suas culturas praticadas em área de um alqueire. A comissão opinou pela instalação provisória da Escola Normal Rural nesse grupo escolar até a construção da sede própria. Depois, na Delegacia de Ensino, foram debatidos os critérios para a instalação da escola determinando os educadores presentes que o estabelecimento deveria funcionar com um curso de continuação de dois anos. Para candidatar-se a matrícula, o aluno deveria prestar exames vestibulares constando de provas escritas de Português e Ciências e o curso conferiria vantagens e deveres aos diplomados: a) preferência de escolha de cadeira localizada na zona rural no concurso de ingresso e, após três anos de exercício, escolha de cadeira em concurso de remoção e, b) obrigatoriedade do candidato a permanecer três anos na escola que escolhesse, residindo no local do seu funcionamento. Para a instalação da Escola Normal Rural, Anísio Teixeira, diretor do Instituto Nacional de Estudos Pedagógicos, destinara uma verba de 1 milhão de cruzeiros, contribuindo ainda com o mobiliário e implementos agrícolas necessários (ESTUDOS PARA A INSTALAÇÃO..., 1956, p. 64).

A inauguração da Escola Normal Rural de Piracicaba ocorreu no dia 03 de agosto de 1956. O OESP noticiou o evento destacando a atuação dos políticos que lograram tal feito: “O decreto da sua criação e instalação data de 1933, tendo sido instalada graças aos esforços dos piracicabanos junto ao governo e pela boa vontade do Dr. Paula Lima, secretario da Educação e do trabalho do Dr. Solon Borges dos Reis, diretor-geral do Departamento de Educação" (INAUGURADA EM PIRACICABA..., 1956, p. 9). Informava o articulista do jornal que, devido à chuva caída no dia programado para a inauguração, a sessão solene que deveria ocorrer no Grupo Escolar "Prof. Corte Brilho", no Bairro do Chicó, foi realizada na cidade, na sede do Instituto Cultural Ítalo-Brasileiro. Estiveram presentes autoridades políticas e educacionais, além de professores e alunos. A sessão foi aberta pelo diretor da escola, professor José Armando Furlan e na sequência, o prof. Solon Borges dos Reis salientou a importância da criação da Escola Normal Rural em Piracicaba. Ainda de acordo com o OESP, “o Prof. Moacyr Campos proferiu a aula inaugural sobre as idéias ruralistas e seus propugnadores, terminando sua alocução com 
uma exortação aos alunos nas suas futuras tarefas de recuperação e elevação das populações rurais." (INAUGURADA EM PIRACICABA..., 1956, p. 9). ${ }^{19}$

A Revista do Professor do Centro do Professorado Paulista, no exemplar de novembro de 1956, fez referência à inauguração ressaltando: "Velho sonho de Sud Mennucci, talvez não tenha sido realizado com a grandeza esperada, mas, embora modestamente, concretizou-se, e isso é o que importa. De nada valeria a permanência das contínuas protelações, sob o pretexto da carência de instalações adequadas, o que fazia falta era vontade e ânimo para enfrentar o problema..." (ESCOLA NORMAL RURAL DE PIRACICABA, 1956, p. 7).

Em outubro de 1956, a escola recebeu a visita de Joaquim Moreira de Sousa, técnico de educação do Ministério da Educação que havia sido diretor da Escola Normal de Juazeiro, no Ceará, além da prof ${ }^{a}$. Chiquinha Rodrigues, ex-deputada estadual que se dedicara à defesa da escola primária e da ruralização do ensino (REIS, 2006).

Em mensagem apresentada à Assembleia Legislativa, em 14 de março de 1957, o governador Jânio da Silva Quadros comunicou a instalação em caráter experimental da Escola Normal Rural de Piracicaba, explicitando de forma clara o problema que envolveu a criação dessa instituição de ensino no estado:

O ensino normal rural, que é uma realidade em vários Estados da Federação, notadamente no Nordeste, fora apenas esboçado em São Paulo, com a criação, em 1931, da Escola Normal Rural de Piracicaba, dispositivo legal que permaneceu letra morta, não revogada mas também não aplicada, desde sua promulgação. As autoridades do ensino e os estudiosos do problema da educação rural em nosso meio não se punham de acordo quanto à conveniência ou não, da solução que esse tipo de escola normal prognosticava para o mal - a instabilidade do professor rural e a impropriedade de seu ensino, divorciado das soluções

\footnotetext{
${ }^{19}$ Foram colocados à disposição da Escola Normal Rural os seguintes professores: Benedito Antonio Cotrim (Português), do Ginásio Estadual de Lucélia; Maria Cecília de Aguiar Ayres (Historia Geral e do Brasil), da Escola Normal e Ginásio Estadual de Santa Barbara d'Oeste; Norman Kerr Jorge (Geografia Geral e do Brasil), da Escola Normal de Capivari; Ruy Madsen Barbosa (Matemática), do Colégio Estadual e Escola Normal de Tietê; Francisco Godoy (Educação Física), do Instituto de Educação "Sud Menucci"; João Fioravanti Junior (Trabalhos Manuais), do Ginásio de Cerqueira Cesar; Lia Penches de Menezes (Trabalhos Manuais e Economia Doméstica, do Ginásio Estadual de Iguape; Tercio Epeneto Emerique (Educação), da Escola Normal e Ginásio Estadual de Santa Barbara d’Oeste; Cecília de Azevedo Godoy (Desenho Pedagógico), do Colégio Estadual e Escola Normal de Araçatuba. Professores primários padrão H: Jaime de Arruda Dias, do Grupo Escolar Rural de Araraquara; Ciro Godoy Orsi, do Grupo Escolar Rural de Taçaindá de Martinópolis" (INAUGURADA EM PIRACICABA..., 1956, p. 9).
} 
sociais e culturais da roça. Rompendo com a rotina, já que tínhamos a lei que nos facultava a ação, promoveu-se a instalação, a título experimental, da referida Escola Normal Rural de Piracicaba, aproveitando para isso o Grupo Escolar do Chicó, bairro daquele município, servido por um ramal da Estrada de Ferro Sorocabana e que oferecia condições satisfatórias para o empreendimento. (SÃO PAULO, 1957, p. 63)

Porém, a consolidação da Escola Normal Rural de Piracicaba foi lenta. Ainda em 1957, alunos e professores tiveram que se mobilizar em defesa dos direitos de ingresso no magistério rural estabelecidos pela legislação de 1950. A esse respeito, o jornal OESP publicou uma nota em 13 de dezembro de 1957, destacando:

\begin{abstract}
Essa situação inquietante para os alunos e professores, deu origem a um movimento para que a escola normal rural de Piracicaba voltasse a gozar das prerrogativas estabelecidas pela lei que a criou. Esse objetivo foi recentemente conseguido, através de ato do governo do Estado, que sancionou lei promulgada pela Assembleia Legislativa. (SITUAÇÃO DOS DIPLOMADOS..., 1957, p. 11)
\end{abstract}

O articulista do jornal referia-se à nova lei aprovada pelo governador Jânio Quadros, em 20 de novembro daquele ano, dispondo sobre a instalação da Escola Normal Rural de Piracicaba (Lei $n^{\circ} 4.420$, de 20 de novembro de 1957). Essa lei determinava que o curso normal rural teria duração de três anos envolvendo um currículo abrangente, que compreendia as seguintes disciplinas: 1) Metodologia do Ensino, 2) Psicologia Geral e Educacional, 3) Anatomia e Fisiologia Humana e Biologia Educacional, 4) Sociologia Educacional e Rural, 5) Higiene, Puericultura e Profilaxia Rural, 6) História da Educação Rural e do Ruralismo, 7) Economia Rural, 8) Português, 9) Ciências Físicas e Naturais, 10) Desenho Pedagógico, 11) Matemática e Noções de Estatística, 12) Educação Física, 13) Música e Canto Orfeônico, 14) Trabalhos Manuais e Economia Doméstica, 15) Agricultura Geral e Especial, 16) Zootecnia, 17) Tecnologia Agrícola.

Ainda de acordo com essa legislação, as cadeiras de Higiene e Profilaxia Rural, de Agricultura Geral e Especial e de Zootecnia seriam ministradas privativamente, por médico, engenheiro e agrônomo e médico veterinário caracterizando assim, a especificidade da formação técnica para as atividades agrícolas. O ingresso no curso 
normal da Escola Normal Rural dependeria de aprovação em exames vestibulares incluindo provas que revelassem o interesse e disposição do candidato para o magistério rural. Os trabalhos escolares seriam divididos em dois períodos, um reservado para as aulas teóricas, em classe e outro para as aulas práticas no campo e nos laboratórios. A lei mantinha a preferência dos alunos diplomados pela escola à nomeação para os cargos de diretor e professor de grupos escolares rurais e para os cargos de professores de escolas típicas rurais (SÃO PAULO, 1957).

Em 10 de janeiro de 1958, foi realizada a cerimônia de colação de grau da primeira turma de professores formada pela Escola Normal Rural “Prof. José de Mello Morais”, de Piracicaba. A notícia publicada na Revista do Professor ressaltou a celebração do evento e a presença de Tales de Andrade, escritor de literatura infantil e professor reconhecido por suas obras relacionadas à educação no campo:

Falaram, em aplaudidas orações, o paraninfo prof. Benedito Cotrim e os patronos drs. Valentim Amaral e o deputado Ortiz Monteiro. No dia seguinte, em seguimento à comemoração, foi plantada uma árvore em terreno da Escola Normal Rural. Desta solenidade o clichê apresenta um aspecto, mostrando-nos o momento em que o mestre Tales Castanho de Andrade, especialmente homenageado, procedia ao plantio de um lindo exemplar de nossa flora. (ESCOLA NORMAL RURAL..., 1958, p. 10)

Em julho de 1960, o jornal OESP publicou uma nota destacando a importância da Escola Normal Rural de Piracicaba que havia recebido a denominação de "Professor José de Melo Moraes". O articulista do jornal afirmou que esse era um dos únicos estabelecimentos de ensino no Brasil especializado na formação de professores para a zona rural, referindo-se, provavelmente, à sua organização em nível de segundo grau. Porém, nessa mesma edição, outra matéria ressaltou as precárias instalações da escola:

A Escola Normal Rural "Prof. José de Melo Moraes" vem funcionando em Piracicaba desde agosto de 1956, em caráter experimental. Este estabelecimento de ensino, único no gênero em todo o Estado, tem como objetivo formar professores primários com especialização rural, capacitados a desempenhar, com maiores possibilidades de êxito, a difícil tarefa de ensinar a educar na zona rural. (...) O curso é de três anos e do 
currículo constam disciplinas especializadas como Agricultura Geral e Especial, Tecnologia Agricola, Zootecnia, Higiene, Puericultura e Profilaxia Rural, Economia Rural e História do Ruralismo.

A escola não possui, até hoje, prédio próprio e adequado, embora para tal fim tenha a Prefeitura Municipal doado ao Estado, já faz anos, o terreno necessário. Funcionou a principio no Grupo Escolar Típico Rural "Prof. Corte Brilho", no bairro do Chicó e depois em ala do prédio da Faculdade de Farmacia e Odontologia. No momento está abrigada pela Escola Superior de Agricultura "Luis de Queiroz", ocupando o velho Pavilhão de Zootecnia e algumas salas do Pavilhão de Engenharia. $O$ problema das instalações inadequadas e insuficientes tende a complicarse já para o próximo ano, com aumento de candidatos a matrícula. (INSTALAÇÕES PRECÁRIAS..., 1960, p. 13)

O problema do ingresso no magistério rural voltou a preocupar os alunos da Escola Normal Rural em 1961, quando o governador Carlos Alberto Alves de Carvalho Pinto propôs alterações no concurso de ingresso e reingresso ao magistério público primário do Estado. Os protestos dos alunos e professores receberam a seguinte nota do OESP:

Os alunos desse estabelecimento de ensino protestam contra o projeto de lei $\mathrm{n}^{\circ} 348$, aprovado em primeira discussão pela Assembléia Legislativa, que regulamenta o ingresso no magistério oficial, instituindo concurso de provas inclusive para os professores formados pela Escola Normal Rural, que gozavam do direito à escolha de classe ou escola na zona rural no primeiro concurso após a formatura. De acordo com o projeto em causa, os professores já formados perderão todos os seus direitos e serão obrigados a fazer curso de especialização. A escola de Piracicaba, que é a única no gênero em todo o Estado, funciona em caráter experimental. (PROTESTOS DOS ALUNOS..., 1961, p. 19)

Notas esparsas no OESP indicam que a escola normal rural de Piracicaba continuou funcionando até a Reforma do Ensino de $1^{\circ}$ e $2^{\circ}$ Graus, em 1971 (Lei 5.692/71). Segundo matéria publicada nesse jornal, em 22 de outubro de 1967, os alunos da Escola Normal Rural de Piracicaba haviam realizado durante o ano uma pesquisa revelando "alta incidência de verminose entre os escolares de grupos primários periféricos de Piracicaba." (HÁ INCIDÊNCIA DE VERMINOSE, 1967, p. 30). Em abril de 1970, OESP ao tecer comentários sobre a falta de vagas nas escolas de Piracicaba mencionou os cursos normais em funcionamento no município sublinhando em tom sombrio o fim das escolas normais em vista da reforma do ensino em curso: "Consta que o curso normal ainda 
funciona no I.E.E. "Sud Mennucci", no C.E.N.E. Monsenhor Jerônimo Gallo e na Escola Normal Rural, devendo formar-se este ano as ultimas turmas de professores, sob a velha estrutura desse tipo de ensino" (PIRACICABA RESOLVE..., 1970, p. 15). O tão sonhado projeto da escola normal rural em São Paulo esvaiu-se no processo de descaracterização da escola normal como modelo de formação de professores primários, pois, com a Reforma do Ensino de $1^{\circ}$ e $2^{\circ}$ Graus (Lei 5.692/71), a formação de professores foi diluída entre as habilitações profissionais do ensino de $2^{\circ}$ grau, transformada em Habilitação Específica para o Magistério - HEM (TANURI, 2000). A partir da década de 1970, outras propostas e políticas para a formação de professores para as zonas rurais foram instituídas no país em âmbito federal e estadual, mas pautadas em diferentes concepções pedagógicas e modelos institucionais.

\section{À guisa de conclusão}

Este estudo preliminar indica a necessidade de investimentos investigativos sobre a formação de professores rurais no estado de São Paulo, especialmente, sobre os cursos de especialização realizados no âmbito dos Institutos de Educação e os cursos mantidos pela Secretaria de Agricultura. É também relevante examinar de que forma os programas do ensino normal vigentes no período e os manuais didáticos incorporaram conteúdos de formação rural para os normalistas. Outra temática que sobressai na análise é a história da Escola Normal Rural de Piracicaba e o esvanecimento dos ideais ruralistas no estado de São Paulo.

A opção pela Escola Normal Rural em detrimento da Escola Normal Regional também chama a atenção e põe em relevo as peculiaridades da configuração da formação de professores nesse estado da federação. Por último, a oposição entre escola normal e cursos de especialização não podem ser vistos apenas como uma predileção pedagógica, mas como um embate político entre posições divergentes, no caso, entre ruralistas e defensores da escola comum. Em síntese, pode-se dizer que a trajetória da formação de professores rurais no estado de São Paulo acompanhou a indefinição política dos governos do estado sobre a educação rural, a qual, apesar da expansão, continuou relegada e desigual em relação à escola primária urbana. 


\section{Referências}

A RURALIZAÇÃO DO ENSINO. Uma palestra com o prof. Sud Mennucci, diretor geral do Ensino. O Estado de S. Paulo, São Paulo, p. 4, 05 abr. 1932. Disponível em:

<http://acervo.estadao.com.br/pagina/\#!/19320405-19133-nac-0004-999-4-not>. Acesso em: 10 out. 2016.

ALMEIDA JUNIOR, Antônio. O excesso de escolas normais no estado de São Paulo.

Revista Brasileira de Estudos Pedagógicos, Rio de Janeiro, v. 9, n. 24, p. 46-51, set./out. 1946.

ANDRADE, Terezinha. O que os diários revelam: práticas de formação de professoras para a escola rural. Curso Normal Regional Sandoval Soares de Azevedo - Ibirité, Minas Gerais, 1956 - 1959. 2006. 152f. Dissertação (Mestrado em Educação) - Pontifícia Universidade Católica de Minas Gerais, Belo Horizonte, 2006.

ARAÚJO, Fátima Maria Leitão. Educação rural e formação de professores no Brasil: gênese de uma experiência pioneira. Cadernos de História da Educação, Uberlândia-MG, v. 10, n. 2, jul./dez. p. 237-255, 2011.

ARAÚJO, Jaqueline Veloso Portela de. Ruralismo pedagógico e escolanovismo em Goiás na primeira metade do século XX: o Oitavo Congresso Brasileiro de Educação. 2012. $219 \mathrm{f}$. Tese (Doutorado em Ciências Humanas) - Universidade Federal de São Carlos, São Carlos, 2012.

BARROS, Pedro Ferreira. Formação de Professor (as) ruralistas em Juazeiro do Norte (CE) (1934-1973): um projeto emancipatório. 2011. 212 f. Tese (Doutorado em Educação) Universidade Federal do Ceará, Fortaleza, 2011.

BRASIL. Decreto-lei n. 8.530 - de 2 de janeiro de 1946. Lei Orgânica do Ensino Normal. In: CAMARA DOS DEPUTADOS. Legislação informatizada. Disponível em: http://www2.camara.leg.br/legin/fed/declei/1940-1949/decreto-lei-8530-2-janeiro-1946458443-publicacaooriginal-1-pe.html. Acesso em: 10 abr. 2015.

BRASIL. Lei de Diretrizes e Bases de 1961 - Lei n 4.024, de 20 de dezembro de 1961. In: Jusbrasil. Disponível em: <http://presrepublica.jusbrasil.com.br/legislacao/129047/lei-dediretrizes-e-base-de-1961-lei-4024-61>. Acesso em: 10 abr. 2015.

BRASIL. Lei 5.692, de 11 de agosto de 1971. Fixa Diretrizes e Bases para o ensino de $1^{\circ}$ e $2^{\circ}$ graus, e dá outras providências. In: CAMARA DOS DEPUTADOS. Legislação informatizada. Brasília. Disponível em: <http://www2.camara.leg.br/legin/fed/lei/1970-1979/lei-5692-11agosto-1971-357752-publicacaooriginal-1-pl.html>. Acesso em: 10 out. 2016.

COMO DEVERIA SER reorganizado o ensino rural em São Paulo. Educação. São Paulo: Orgão da Directoria Geral do Ensino de São Paulo, v. VIII, n. 6 e 7, jun./ jul. 1932, p. 190 195. 
EDUCAÇÃO rural. Educação, São Paulo: Typ. Siqueira, v. 15 e 16, p. 103-115, set./dez. 1936.

ENSINO rural. O Estado de S. Paulo, São Paulo, p. 5, 13 dez. 1931. Disponível em: <http://acervo.estadao.com.br/pagina/\#!/19311213-19040-nac-0005-999-5-not>. Acesso em: 12 out. 2016.

ESCOLA normal rural. O Estado de S. Paulo, São Paulo, p. 5, 23 abr. 1949. Disponível em: <http://acervo.estadao.com.br/pagina/\#!/19490423-22678-nac-0005-999-5-not>. Acesso em: 12 out. 2016.

ESCOLA normal rural em Piracicaba. O Estado de São Paulo, São Paulo, p. 10, 30 mar. 1956. Disponível em: <http://acervo.estadao.com.br/pagina/\#!/19560310-24801-nac-0010999-10-not>. Acesso em: 12 out. 2016.

ESCOLA normal rural. O Estado de S. Paulo, São Paulo, p. 108, 14 out. 1956. Disponível em: <http://acervo.estadao.com.br/pagina/\#!/19561014-24986-nac-0108-999-108-not>. Acesso em 11 out. 2016.

ESCOLA Normal Rural de Piracicaba. Revista do Professor. São Paulo: Centro do Professorado Paulista, n. 30, p. 7, nov. 1956.

ESCOLA Normal Rural “Prof. José de Mello Morais". Revista do Professor. São Paulo: Centro do Professorado Paulista, n. 39, p. 10, fev./ mar. 1958.

ESTUDOS para instalação de uma Escola Normal Rural em Piracicaba. O Estado de S. Paulo, São Paulo, p. 64, 15 abr. 1956. Disponível em:

<http://acervo.estadao.com.br/pagina/\#!/19560415-24831-nac-0064-999-64-not>. Acesso em: 11 out. 2016.

FÁVERO, Maria de Lourdes de Albuquerque; BRITTO, Jader de Medeiros (Org.s).

Dicionário de educadores no Brasil: da Colônia aos dias atuais. 2 ed. Rio de Janeiro: Editora UFRJ / MEC - Inep - Comped, 2002, p. 131-137.

FONSECA, Henrique de Oliveira. Em defesa da ruralização do ensino: Sud Mennucci e o debate político educacional entre 1920 e 1930. 2014. 159 f. Dissertação (Mestrado em Educação) - Faculdade de Educação, Universidade Federal de Minas Gerais, Belo Horizonte, 2014.

Há incidência de verminose. O Estado de S. Paulo, São Paulo, p. 30, 22 out. 1967. Disponível em: <http://acervo.estadao.com.br/pagina/\#!/19671022-28383-nac-0030-999-30not>. Acesso em: 12 out. 2016.

HERVATINI, Luciana. A Escola Normal Regional e suas práticas pedagógicas: dois retratos de um mesmo cenário no interior do Paraná. 2011. 256 fls. Dissertação (Mestrado em Educação) - Universidade Estadual de Maringá. Maringá, PR, 2011. 
INAUGURADA em Piracicaba a $1^{\text {a }}$ Escola Normal Rural do Estado. O Estado de S. Paulo, São Paulo, p. 9, 11 ago. 1956. Disponível em:

<http://acervo.estadao.com.br/pagina/\#!/19560811-24931-nac-0009-999-9-not>. Acesso em: 10 out. 2016.

INSTALAÇÕES precárias na Escola Rural. O Estado de S. Paulo, São Paulo, p. 13, 16 jul. 1960. Disponível em: <http://acervo.estadao.com.br/pagina/\#!/19600716-26140-nac-0013999-13-not>. Acesso em 15 abr. 2015.

INSTRUÇÃO pública e educação. Escola Normal Rural em Piracicaba. O Estado de S. Paulo, São Paulo, p. 10, 20 mar. 1956. Disponível em:

<http://acervo.estadao.com.br/pagina/\#!/19560320-24809-nac-0010-999-10-not>. Acesso em: 15 abr. 2015.

KULESZA, Wojciech Andrzej. Entre o conformismo e a redenção: o caso da Escola Normal Rural de Juazeiro do Norte. In: WERLE, Flávia Obino Corrêa. Educação rural: práticas civilizatórias e institucionalização da formação de professores. São Leopoldo: Oikos; Brasília: Líber Livro, 2010.

MENNUCCI, Sud. A crise brasileira de educação. São Paulo, [1930], 2006. Disponível em: http://www.ebooksbrasil.org/eLibris/sudeducacao.html. Acesso em 23: fev. 2015.

MENNUCCI, Sud. A reforma do ensino rural em S. Paulo. In: Educação, São Paulo: Órgão da Directoria Geral do Ensino de São Paulo, v. IV, n. 1 e 2, ago. / set, 1931, p. 2-11.

MENNUCCI, Sud. O que fiz e o que pretendia fazer: defesa e fundamentação da reforma do ensino de 1932. São Paulo: Editora Piratininga, 1932.

MONARCHA, Carlos. Cânon da reflexão ruralista no Brasil: Sud Mennucci. In: WERLE, Flavia Obino Corrêa (Org.). Educação rural em perspectiva internacional: instituições, práticas e formação do professor. Ijuí: Ed. UNIJUÍ, 2007. p. 19-51.

MORAES, Agnes lara Domingos. Ensino primário tipicamente rural o estado de São

Paulo. Granjas escolares, grupos escolares rurais e escolas típicas rurais (1933-1968). São Paulo: Cultura Acadêmica, 2015. (Coleção PROPG - Unesp).

NOGUEIRA, Delane Lima. Amália Xavier e a Escola Normal Rural de Juazeiro do Norte; registros sobre a constituição de uma cultura docente para a educação no campo. 2008. 200 f. Dissertação (Mestrado em Educação) - Universidade Estadual do Ceará, Fortaleza, 2008.

NOTAS e informações. O Estado de S. Paulo, São Paulo, p. 3, 15 maio 1949. Disponível em: <http://acervo.estadao.com.br/pagina/\#!/19490515-22697-nac-0003-999-3-not>. Acesso em: 10 abr. 2015. 
NOTÍCIAS do interior. O Estado de S. Paulo, São Paulo, p. 9, 13 maio 1949. Disponível em: <http://acervo.estadao.com.br/pagina/\#!/19490513-22695-nac-0009-999-9-not>. Acesso em: 12 abr. 2015.

PAES, Ademilson B. A escola primária rural em Mato Grosso do Sul no período republicano (1889 - 1942). 2011. 268f. Tese (Doutorado em Educação Escolar) - Faculdade de Ciências e Letras, Universidade Estadual Paulista, Araraquara, 2011.

PIACENTINE, Ana Paula Fernandes da Silva. História da formação para professores leigos rurais: o curso de magistério rural em Dourados, na década de 1970. 2012. 102

f. Dissertação (Mestrado em Educação) - Universidade Federal da Grande Dourados, Dourados, 2012.

PINCER, Valeska de Mello. A formação de professores nos Cursos de treinamento e Aperfeiçoamento do Instituto Superior de Educação Rural - ISER, Fazenda do Rosário: 1955 - 1970. 2008. 133 f. Dissertação (Mestrado em Educação) - Pontifícia Universidade Católica de Minas Gerais, Belo Horizonte, 2008.

PINTO, Helder de Moraes. A Escola Normal Regional Dom Joaquim Silvério de Souza de Diamantina e a formação de professores para o meio rural mineiro: 1950 - 1970. 2007. 199 f. Dissertação (Mestrado em Educação) - Pontifícia Universidade Católica de Minas Gerais, Belo Horizonte, 2007.

PIRACICABA resolve problema de vagas. O Estado de S. Paulo, São Paulo, p. 15, 03 abr. 1970. Disponível em: <http://acervo.estadao.com.br/pagina/\#!/19700403-29136-nac-0015999-15-not>. Acesso em: 11 abr. 2015.

PRADO, Adonia Antunes. Intelectuais e educação no Estado Novo (1937 - 1945): o debate sobre a formação do professor primário rural. Teias, Rio de Janeiro, n. 1, p. 46-55, jan./jun. 2000.

PROTESTOS dos alunos da Escola Normal Rural. O Estado de S. Paulo, São Paulo, p. 19, 19 set. 1961. Disponível em: <http://acervo.estadao.com.br/pagina/\#!/19610919-26505-naco019-999-19-not>. Acesso em 12 abr. 2015.

REIS, Eliana de Jesus. O parlamento paulista e a questão educacional: uma análise dos discursos de Chiquinha Rodrigues (1935 - 1937). 2006, 120 f. Dissertação (Mestrado em Educação: História, Política e Sociedade) - Pontifícia Universidade Católica de São Paulo, 2006.

SANGENIS, Luiz Fernando C.; CONSIDERA, Marcela Lovos. Formação de professores para escolas rurais: o Curso Normal Rural de Cantagalo (1952 - 1962). Revista Eletrônica Pesquiseduca, Santos, v. 5, n. 9, p. 63-87, jan./jul. 2013. Disponível em: $<$ http://periodicos.unisantos.br/index.php/pesquiseduca/article/viewFile/293/pdf >. Acesso em: 04 dez. 2016. 
SANTANA, Maria do Perpetuo Socorro Castelo Branco. A constituição da rede escolar e a prática das professoras primárias na zona rural do Piauí nos anos de 1940 a 1970. 2011, 178 f. Dissertação (Mestrado em Educação) - Universidade Federal do Piauí, Teresina, 2011.

SÃO PAULO (Estado). Decreto n. 6.047, de 19 de agosto de 1933: Instala uma Escola normal rural, em Piracicaba. In: ASSEMBLEIA LEGISLATIVA DO ESTADO DE SÃO PAULO. Legislação. Disponível em: <http://www.al.sp.gov.br/norma/?id=131333>. Acesso em: 15 abr. 2015.

SÃO PAULO (Estado). Annuário do Ensino do Estado de São Paulo: 1935-1936. São Paulo: Tip. Siqueira, [1937]. Publicação organizada pela Directoria Geral da Instrucção Pública por ordem do governo do Estado.

SÃO PAULO (Estado). Decreto n. 17.698, de 26 de novembro de 1947: aprova a consolidação mandada elaborar pelo decreto n. 17.211, de 13 de maio de 1947. In: COLEÇÃO das Leis e Decretos do Estado de São Paulo de 1947. Tomo LVIII. $4^{\circ}$ trimestre. $1^{\circ}$ volume. São Paulo: Imprensa Oficial do Estado, 1948.

SÃO PAULO (Estado). Decreto n 19.525-A, de 27 de junho de 1950: Institui o Regimento Interno das Escolas Normais Oficiais do Estado. In: ASSEMBLEIA LEGISLATIVA DO ESTADO DE SÃO PAULO. Legislação. Disponível em: <http://www.al.sp.gov.br/norma/?id=101662>. Acesso em: 12 abr. 2015.

SÃO PAULO (Estado). Lei n ${ }^{\circ} 881$, de 6 de dezembro de 1950. Dispõe sobre instalação de uma escola normal rural em Piracicaba, de acordo com o Decreto n. 6.047, de 19 de agosto de 1933, e dá outras providências. In: ASSEMBLEIA LEGISLATIVA DO ESTADO DE SÃO PAULO. Legislação. Disponível em: <http://www.al.sp.gov.br/norma/?id=44617>. Acesso em: 12 abr. 2015.

SÃO PAULO (Estado). Decreto $n^{\circ} 25.781$, de 27 de abril de 1956. Dispõe sobre a instalação de uma Escola Normal Rural em Piracicaba, nos termos da Lei 881, de 6 de dezembro de 1950. In: ASSEMBLEIA LEGISLATIVA DO ESTADO DE SÃO PAULO. Legislação. Disponível em: <http://www.al.sp.gov.br/norma/?id=108255>. Acesso em: 15 abr. 2015.

SÃO PAULO (Estado). Lei n. 3.739, de 22 de janeiro de 1957. Dispõe sôbre organização do ensino normal no Estado de São Paulo. In: ASSEMBLEIA LEGISLATIVA DO ESTADO DE SÃO PAULO. Legislação. Disponível em:

<http://www.al.sp.gov.br/repositorio/legislacao/lei/1957/lei-3739-22.01.1957.html>. Acesso em 02 abril 2015. Acesso em: 12 abr. 2015.

SÃO PAULO (Estado). Lei n. 4.420, de 20 de novembro de 1957. Dispõe sobre a instalação de Escola Normal Rural, em Piracicaba, criada pela Lei n ${ }^{\circ} 881$, de 6 de novembro de 1950. In: ASSEMBLEIA LEGISLATIVA DO ESTADO DE SÃO PAULO. Legislação. Disponível em: <http://www.al.sp.gov.br/norma/?id=38837>. Acesso em: 05 set. 2016. 
SÃO PAULO (Estado). Decreto n. 35.100, de 17 de junho de 1959. Regulamenta a Lei n. ${ }^{\circ}$ 3.739, de 22 de Janeiro de 1957. In: ASSEMBLEIA LEGISLATIVA DO ESTADO DE SÃO PAULO. Legislação. Disponível em:

<http://www.al.sp.gov.br/repositorio/legislacao/lei/1962/lei-6792-13.04.1962.html>. Acesso em: 05 abril 2015.

SÃO PAULO (Estado). Decreto $n^{\circ} 38.538$, de 2 de fevereiro de 1961. Aprova o regimento interno dos estabelecimentos de ensino secundário e normal do Estado de São Paulo. In: ASSEMBLEIA LEGISLATIVA DO ESTADO DE SÃO PAULO. Legislação. Disponível em: <http://www.al.sp.gov.br/norma/?id=119240>. Acesso em: 5 de out. 2016.

SÃO PAULO (Estado). Decreto ${ }^{\circ}$ 38.634, de 23 de junho de 1961. Aprova a nova redação dos artigos 91, 104, 105, 106 e 107 do Regimento Interno dos estabelecimentos de ensino secundário e normal do Estado de São Paulo. In: ASSEMBLEIA LEGISLATIVA DO ESTADO DE SÃO PAULO. Legislação, [2016]. Disponível em:

<http://www.al.sp.gov.br/norma/?id=119336>. Acesso em: 5 out. 2016.

SÃO PAULO (Estado). Lei n 10.038 , de 5 de fevereiro de 1968. Dispõe sobre a organização do Sistema de Ensino do Estado de São Paulo. In: ASSEMBLEIA LEGISLATIVA DO ESTADO DE SÃO PAULO. Legislação. Disponível em: <http://www.al.sp.gov.br/norma/?id=28320>. Acesso em: 15 abr. 2015.

SÃO PAULO (Estado). Lei n 10.125, de 4 de junho de 1968. Institui o Código de Educação do Estado de São Paulo. In: ASSEMBLEIA LEGISLATIVA DO ESTADO DE SÃO PAULO. Legislação. Disponível em: <http://www.al.sp.gov.br/norma/?id=28428>. Acesso em: 15 abr. 2015.

SÃO PAULO (Estado). Decreto $n^{\circ} 50.133$, de 2 de agosto de 1968. Regulamenta a Lei ${ }^{\circ}$ 10.038, de 5 de fevereiro de 1968 na parte relativa ao ensino colegial secundário e normal. In: ASSEMBLEIA LEGISLATIVA DO ESTADO DE SÃO PAULO. Legislação. Disponível em: <http://www.al.sp.gov.br/norma/?id=84887>. Acesso em: 15 abr. 2015.

SÃO PAULO (Estado). Mensagem apresentada pelo Governador Adhemar de Barros à Assembléia Legislativa a 14 de março de 1948. São Paulo, 1948.

SÃO PAULO (Estado). Mensagem apresentada pelo governador Janio Quadros à Assembléia Legislativa do estado de São Paulo em 14 de março de 1957. São Paulo, [s/d].

SÃO PAULO (Estado). Mensagem apresentada pelo Governador Lucas Nogueira Garcez à Assembléia Legislativa do Estado de São Paulo, 14 de março de 1952. São Paulo, 1952.

SITUAÇÃO dos diplomados pela Escola Normal Rural. O Estado de S. Paulo, São Paulo, p. 11, 13 dez. 1957. Disponível em: <http://acervo.estadao.com.br/pagina/\#!/19571213-25343nac-0011-999-11-not>. Acesso em: 05 set. 2016. 
TANURI, Leonor Maria. História da formação de professores. Revista Brasileira de Educação, n. 14, mai/jun/jul/ago, 2000. p. 61-88. Disponível em:

<http://www.scielo.br/pdf/rbedu/n14/n14a05.pdf>. Acesso em: 4 dez 2016.

VIVIANI, Luciana Maria; GIL, Natália de Lacerda. A expansão e a eficiência da escola rural em São Paulo: atuação e posicionamentos de Almeida Junior a partir de estatísticas oficiais. História da Educação, v. 15, n. 34, p. 147-170, maio/ago. 2011. Disponível em: <http://seer.ufrgs.br/asphe/article/view/20355>. Acesso em: 22 out. 2016.

WERLE, Flávia O. Corrêa; METZLER, Ana Maria. Contextos, institucionalização e práticas pedagógicas em Escolas Normais Rurais. In: WERLE, Flávia Obino Corrêa (org.). Educação rural: práticas civilizatórias e institucionalização da formação de professores. São Leopoldo: Oikós; Brasília: Líber Livro, 2010, p. 15-32. 